\title{
Countering Popular Misconceptions of Federal Bureaucracies in American Government Classes
}

\author{
David J. Lorenzo, Jamestown College
}

In teaching classes in American politics, I find mysclf in the position of returning to the classroom with practical government experience. After teaching introductory American government classes at a large state university, I worked for the U.S. Department of Education as a policy specialist for two years before returning to academia at a small liberal arts college.

I have noted several benefits of government experience. One acquires a bit of added authority from being someone who has actually participated in the processes and events described. I also have a useful catalogue of war stories and amusing anecdotes to relate that chronicle the confusion, stupidity, or hubris of the various players. But most important of all is an added awareness. In particular, I am now able to detect and counter on campus a number of misconceptions of the independence, role, and responsiveness of federal bureaucracies. I have found that my students, like many other ordinary citizens, tend to believe misleading stories that depict federal bureaucrats as possessing broad discretion for which they are unaccountable, contend that bureaucrats create regulations while isolated in an ivory tower, and assume that citizens have no way of influencing the actions of bureaucracics.

As Fiorina (1977) noted, Congress is an important source of these stories. One of the best reelection strategies congresspeople have at hand is blaming all problems on bureaucrats. If disaster strikes the country, bureaucrats are at fault.

David J. Lorenzo is assistant professor of history and political science at Jamestown College, where he teaches American politics and political theory. His most recent publication is Tradition and the Rhetoric of Right: Popular Political Argument in the Aurobindo Movement (Fairleigh Dickinson University Press, 1999).
Congress rises to meet the challenge by directing bureaucracies to resolve the problem by issuing new regulations or implementing programs requiring new regulations. Congress then accuses bureaucrats of dreaming up new government restraints on honest citizens and businessmen. I have noticed this rhetoric creeping into the discourse of my students, and influencing their perceptions of the federal government.

Early last year, I felt compelled to write an article in my college's conservatively oriented student paper on this subject. The paper had admiringly reprinted Rep. James Traficant's (D-OH) "One-Minute Speech" titled "Regulations Cost the Taxpayers Billions," in which Traficant complained that federal regulation "costs taxpayers $\$ 400$ billion, cvery year, year in, year out." His solution was to "yield back all the reg writing bureaucrats in Washington, DC, who never stood in an unemployment line." The editors of the newspaper thought this an excellent line of analysis. Though I countered by citing Fiorina, I was frustrated that college students would accept such a glib position.

While working for the Department of Education, I had earlier experienced the width of the audience these popular misconceptions find. Once, while meeting with a public task force on a project dealing with the congressionally mandated reporting of educational statistics, I dismayed a political scientist on the task force by informing him that the department would not agree to a regulatory formulation that contradicted the methodology contained in the statute. Why was I being so stubborn? After all, he argued, bureaucrats are like cops on the beat. They have discretion in applying the law, and that discretion can take the form of a decision not to apply the law in a particular situation. Wasn't I just arbitrarily exercising my bu- reaucratic power? It was my turn to be dismayed. How could someone who had told me he taught American government at a prestigious university so profoundly confuse the responsibilities of a policeman on the streets with the responsibilities of executive branch officials who translate sometimes very detailed statutes into general regulations and rules? And even more dismaying, how could he believe that our Office of General Counsel would blithely sign off on a deal that ignored a statutory provision? The degree of discretion he assumed department personnel possessed was much greater than the real amount of autonomy I knew we enjoyed, and his easy assumption that we were unaccountable to Congress was profoundly disturbing.

\section{The Limitations of Textbooks ${ }^{2}$}

I think the reasons such misconceptions persist on college campuses go beyond the influence of political rhetoric. Such rhetoric finds fertile ground in part because introductory American government textbooks necessarily must devote very limited space to discussions of bureaucracies.

I recently compared five textbooks while considering revisions to my introductory American National Government syllabus. These texts were Morris Fiorina and Paul E. Peterson's The New American Domocracy (1999); Kenneth Janda et al.'s The Politics of American Government (1998); William Lasser's American Politics: The Enduring Constitution (1999); Karen O'Connor and Larry Sabato's The Essentials of American Government: Continuity and Change (1998); and Stephen Wayne et al.'s The Politics of American Government (1998). This comparison was partial and random, including only those text- 
books publishers had sent me. Part of my comparison involved discussions of the federal bureaucracies. While I found the textbooks overall to be excellent, I also found most discussions of bureaucracies to be deficient on the topics of discretion, outside influences, and popular participation.

All the texts contain sections addressing the practical reasons why Congress delegates authority to the executive branch, the problems associated with bureaucracies and regulations (including problems of accountability), and the existence of iron triangles. But three of the texts contain very limited discussions of congressional constraints on the amount of discretion bureaucracies exercise, and one account leaves the impression that all bureaucracies are unencumbered by statutory constraints. One textbook has no discussion of the rule-making process, the Federal Register, or the Code of Federal Regulations, and no indication that ordinary citizens may participate in the creation of regulations. Three texts contain discussions of the role of congressional hearings that range from one to three sentences in length. Three texts only discuss iron triangles in the classic sense, and do not discuss attempts by interest groups, sometimes in league with congresspeople, to influence, cajole, or threaten bureaucracies to adopt particular policies or enforce policies in certain ways. Even the two texts that do, in my opinion, provide adequate discussions of all these topics, keep discussions theoretical and contain little of the passion or anecdotal evidence that congressional and other sources of misconceptions so effectively employ.

My admittedly brief survey suggests that a majority of textbooks are unlikely to contain the detailed discussions of bureaucracies necessary to counteract the popular misconceptions of bureaucracies discussed above. It is perhaps asking too much of textbooks that they do so. There is, after all, much to cover and little space available. Given this situation, I believe it is advantageous for instructors to create additional, practical activities to provide the information that the most deficient textbooks leave out. For even those instructors who use the best of textbooks, I think it is useful to supplement those texts to counter the volume and passionate context of the misinformation students receive from other sources. I supplement my text by taking students closer to the political process. I require students to examine documents, view political events, and participate in political processes. Below, I discuss three areas of bureaucratic action and processes that I think are the subject of deeply rooted misconceptions and outline the activities I use in my classes to supplement textbook discussions and counter those misperceptions.

\section{Countering Misconceptions}

\section{The Autonomy of Bureaucracies}

Perhaps the most deeply rooted and persistent misconception about bureaucrats is that they are not accountable to, and operate independently of, Congress. Whether bureaucrats possess more power than they should is a normative question to be explored with one's class, but as discussed above, I find that the discussions of the executive branch and bureaucracies found in textbooks are insufficient to convey the structural and political constraints that actually exist for bureaucracies. Descriptions of bureaucrats "administering programs" and "applying laws" do not adequately counteract the popular notion that bureaucracies have an almost totally free hand in running the government on a dayto-day basis. Indeed, I found one text feeds this misconception through its extensive discussion of "administrative discretion." While there are differences in the autonomy various departments of the federal government enjoy--the State Department has significantly more discretion than social welfare departments, for instance-there is a hardy popular assumption that all federal departments operate in an unfettered fashion.

To counter this misconception, discussions of congressional con- straints should accompany discussions of bureaucratic discretion. I use the very familiar case of federal student financial aid as an example. I start with the legislation authorizing the student aid programs, move to the Department of Education regulations governing those programs, and end with the Free Application for Federal Student Assistance (FAFSA). I emphasize the detail of the statute, the amount of discretion explicitly allowed in the statute, and how one can trace the provisions of the statute through the regulations and into the content of the FAFSA. I believe this shows much more clearly than textbooks the level of control Congress retains over the administration of some programs, how closely bureaucrats must cleave to statutory provisions, and the fact that in all cases Congress controls the amount of discretion bureaucracies enjoy. This then sets the stage for an informed discussion of bureaucratic independence and power.

\section{Interest Groups, Congress, and Bureaucracies}

I think textbooks also fail to describe adequately the amount of effort congresspersons and special interests expend in attempting to influence the actions of bureaucracies, both within and outside the areas of bureaucratic discretion. Bureaucracies are popularly depicted as being insulated against outside input in their creation of policies and regulations. This depiction may seem accurate because many attempts to influence policy making are hidden from view, being made during face-to-face meetings, over the telephone, and through letters. While discussions of iron triangles help illuminate part of the phenomenon, they are not sufficient. It is not only important to recognize that special interest groups give support to bureaucracies in order to protect favored programs. It is also important to show that special interest groups attempt (for good or ill) to influence bureaucratic policy making and that these groups use Congress as leverage in those efforts.

Special interests do attempt to 
influence the decisions of bureaucrats. Bureaucrats are, to a degree, receptive to those efforts. From the bureaucratic point of view, it is always better to develop a working relationship with special interests than an antagonist one, and input from those whom policies directly affect is an important resource. From the special interest point of view, lobbying bureaucrats is a natural extension of lobbying Congress. To them, actions of the executive branch are continuations of the political process, to be influenced to produce a congenial outcome.

This relationship between bureaucrats and special interest groups is not always gentlemanly. Special interests often invoke the threat of congressional interest. This is a powerful weapon that is sometimes sufficient to influence a policy decision in a favorable direction. The hint of a congressional inquiry, or a letter that references a member of Congress, makes upper level management very nervous and prone either to inaction or very precipitous action. High departmental officials do not want to be called on the carpet before a congressional committee, or antagonize a key member of Congress when an important piece of legislation is in the works.

However, such threats do not always work. Bureaucrats sometimes fight back, especially when it appears that uninformed congresspeople are meddling on behalf of special interests in ways that contradict the law. An appreciable amount of time and effort goes into answering congressional inquiries with a polite request to "buzz off." On several occasions I was tasked with drafting responses to inquiries from congresspeople that revealed a deep (one almost dares say invincible) ignorance of the substance of relevant statutes. Sometimes the department received requests to take actions that directly contravened the plain and explicit language of relevant statutes. At other times we were asked to justify actions that were clearly and specifically mandated by statute. In the midst of such confusion, one was tempted to ask what congresspeople do that leaves them in such a statutory fog. But, on further reflection, perhaps these were cases of Congress purposely pinning blame on bureaucracies for electoral purposes, a point I make in class to support Fiorina's thesis.

While the textbooks I surveyed discuss the general tendency of bureaucracies to move slowly and conservatively in order to escape messy public mistakes, and briefly discuss the role of committee hearings as a means of congressional control, they mostly miss the complexity of interactions among Congress, interest groups, and bureaucracies. They do not sufficiently emphasize the effects of lobbying, interest groups' use of Congress, or bureaucratic responses, and, thus, do not adequately describe the politicized atmosphere in which bureaucracies operate. ${ }^{3}$

This is a difficult problem to remedy. I have resources to draw upon documenting these interactions (constituent letters to congresspeople, Congress's letters to the executive branch, and the responses I made to those inquiries) unavailable to most instructors. Perhaps the best readily available sources are congressional hearings, live or on tape from C-SPAN. Viewing a congressional hearing in which executive branch officers, congresspeople, and representatives of interest groups testify will give students a flavor of the complex relationships among Congress, bureaucrats, and special interest groups. One can note, in particular, the mixture of cooperation and antagonism displayed, as well as how, in general, special interest groups attempt to use Congress to influence bureaucrats, how congresspeople often push the agenda of particular interest groups, and how bureaucrats fight back. While hearings will not completely reveal the scope and intensity of the efforts to influence policy making that take place on a daily basis, they will give students a flavor of the relevant political relationships and how those relationships influence policy making.

\section{Public Participation in the Regulatory Process}

If textbooks inadequately describe the operation of interested parties and congresspersons in the adminis- tration of programs, they mostly neglect the role ordinary citizens can play in the regulatory process. I find it ironic that much space is devoted to the president's staff, of which most students will have little personal experience, while almost none is devoted to the regulatory process, which will affect all students no matter their profession. There are few mentions of the Federal Register, almost no reference to the Code of Federal Regulations, and relatively little discussion of how citizens may participate in the creation of federal rules and regulations. This, of course, reflects and bolsters popular beliefs that ordinary citizens are powerless to influence bureaucracies.

There is, in fact, a regulatory process that students would do well to study. Not only are there rules governing federal student financial aid, but regulations also affect health care, automobile safety, hunting and game management, and a whole host of other topics. No matter what field they enter after college, students will confront federal regulations, and the ability to read and understand federal regulations and participate effectively in the regulatory process will be enormously useful to them. Insofar as Congress gives bureaucracies discretion in writing rules, it is important that students understand how they may participate in that writing process. And given the fact that many students will take only one, introductory, government course in their college career, I think it is important that students in that course be given practical training in how to participate.

To counter the perception that citizens cannot influence the regulatory process, and to give students the tools to participate in that process effectively, I provide students with both basic training and practical experience.

Training involves first acquainting students with the Federal Register, the newspaper of the federal government. I provide information on where to find it and how it is organized. Second, I explain to them the regulatory process, emphasizing the requirements for agencies to publish 
a Notice of Proposed Rulemaking (NPRM) that contains regulatory proposals and solicits comments on those proposals. Next, I explain how to read an NPRM, including how to follow the Code of Federal Regulations format. Finally, I explain the details of a Notice of Final Regulations, emphasize that bureaucracies must analyze and respond to comments, and show students where to look to examine how specific comments shaped final regulations.

Having given students information about the process of rule making, I then require them to complete a group project that utilizes that information and gives them practice in generating staff work. I generally ask them to form groups of three or four people and to complete the following tasks.

1. Each group is to decide on a topic that interests them. I emphasize that each group should pick a topic in which several members have knowledge or interest. For example, nursing students do well to look for hospital and other healthrelated regulations. Hunting enthusiasts can examine game management regulations. (Alternatively, the instructor may wish to provide a ready-made topic and a web site address to download an appropriate NPRM). ${ }^{4}$

2. Each group is to go to the Federal Register website (www. access.gpo.gov/su_docs/aces/ aces $140 . \mathrm{html})^{5}$ and look for an NPRM that falls within its area of interest. Students should take into account the length of the NPRM and the type of specialized knowledge necessary to understanding it. Analyzing and responding to a 300 page NPRM will probably not be a feasible project. Likewise, English majors who have never taken a physics course should not try to tackle the Energy Department's nuclear safety regulations.

3. Each group is to make a copy of the NPRM to turn in along with the materials listed below. This provides proof that the group has actually located an NPRM and has understood it.

4. Each group is to read and analyze the NPRM it has chosen, and prepare a written executive summary of the NPRM addressed to the instructor as the responsible official of a fictional entity that is inter- ested in this set of regulations. (In the words of one student, this summary is addressed to the instructor as the students' boss). I emphasize that heads of companies or government agencies do not have great amounts of time. Executive summaries should be economical (less than one page in length, usually in bullet form).

5. Each group is to prepare a written analysis of the proposed rules from the standpoint of the fictional entity of which they are employees, addressed to the instructor as the boss. Again this analysis should be sharply focused, but provide all the information, analysis, and substantive reasons necessary to support their recommendations regarding particular regulations (two-three pages).

6. Each group is to prepare a letter to the regulatory agency for the instructor's signature as the students' boss. In talking to students about these letters, I emphasize several lessons gained from my practical experience.

a. A critique of a particular regulation that contains concrete proposals detailing how the commenter proposes to change (or replace) the proposed regulation(s) has a much greater impact than a critique alone, and much more impact than a general letter of opposition. Students should support critiques with arguments and provide alternatives. Bureaucrats responsible for promulgating regulations are swayed by well-argued criticisms. Commenters' suggestions provide bureaucrats with their most reliable indicator of what the public wants. In addition, the tactic of taking changes from the comments is the legally safest way for bureaucrats to change a set of proposed rules.

b. A savvy participant in the regulatory process will write letters not only when he or she wishes to critique a set of proposed rules, but also when he or she supports the proposed rules as they stand. Members of the public generally believe that participation is important only when something is "wrong," and neglect to comment when they approve of the content of proposed rules. I explain to students that if they do not submit comments in support of proposed regulations they favor, they are likely to be disappointed in the outcome. When all the comments a bureaucracy receives are criticisms, it is likely that the proposed rules will be changed for the worse, or be open to legal challenge and possibly thrown out altogether. Bureaucrats need the political and legal cover of outside support to stick to their guns in the face of criticisms, and it is up to supporters of a particular version of a rule to provide that cover.

c. Polite letters are the most effective weapons. One owner of an cducational institution greeted every proposed rulc from my office, however trivial or commonsensical, with a fanatic outrage that expressed itself in uncomplimentary names and allegations of dark and evil designs on the part of the department. Needless to say, such contributions were given short shrift. Not only did we, like all humans, react negatively to such diatribes but, also, what use could we make of them?

7. Each student is to prepare an evaluation of the project, detailing what he or she learned from the rule-making exercise and from the group experience. This individual assignment leads students to reflect on the materials and political processes they have experienced, permits them to blow off any steam about the laggards in their group, and allows them to evaluate the whole experience of working in a group.

\section{Conclusion}

I argue that instructors should go byond textbook materials in order to counter misperceptions of bureaucracies. The techniques I use depend on practical experience, both my own as the instructor, and that which students will acquire as part of the course.

I try to translate my experience in federal government into practical lessons. The information I can bring from government is not highly theoretical, nor is it likely to change radically the ways students perceive the overall structure and function of American government. It is more a matter of bringing to the classroom original documents, and experiences of actual events and processes, in order to convey a more accurate 
understanding of the federal government, and to counter misperceptions that seem to be universally accepted. I operate mainly by commenting on these documents, events, and processes from the standpoint of my experience.

I also attempt to give students practical experience by putting them in situations similar to those they may confront in the future. Evaluating regulations, working in groups, generating staffwork, and reporting to a boss are all part of the everyday responsibilities of many people who work in business, law, and government. I believe the more practical experience in these areas students acquire in college, the better fitted they will be as citizens and employees.
Student assessments of these discussions and projects have been overwhelmingly positive. Student evaluations of in-class discussions of materials, especially those touching on relations between congresspeople and bureaucrats, indicate that they are very helpful in helping students understand the complexity of that relationship, and grasp the limitations of bureaucratic discretion. Evaluations of the group regulatory projects have emphasized a greater appreciation of both the scope and complexity of regulatory activity, and surprise that citizens are able to participate in the regulatory process. Criticisms of the projects have dealt mainly with logistical concerns regarding group activities (problems in getting all members of a group to- gether at one place and time; difficulties in dividing the work evenly), and requests to have available as guides exemplary projects from former classes.

Overall, I have found these techniques to be useful and necessary, given the very broad generalizations or lack of information in textbooks and the effects of congressional rhetoric. I have also found that these approaches have the added benefit of generating interest and enthusiasm. When allowed to view documents and to participate in an actual process, rather than merely being asked to read descriptions in textbooks, students tend to identify themselves as political scientists, which is the most satisfying outcome of all.

\section{Notes}

1. As a result of the lobbying efforts of an influential athletic association, Congress eventually changed the statute to reflect the wishes of the task force.

2. While the suggestions I make can also profitably be used in upper-division American government classes, I focus here on introductory classes and textbooks.

3. Randall Ripley and Grace Franklin (1999) discuss many of these points.

4. A student suggested this alternative in his feedback report.
5. Those who have access to the paper version of the Federal Register may still want their students to use this GPO web site, because it has a search engine that will simplify student searches.

\section{References}

Fiorina, Morris P. 1977. Congress: Keystone of the Washington Establishment. New Haven: Yale University Press.

- and Paul E. Peterson. 1999. The New American Democracy. Alt. ed. Boston: Allyn and Bacon.

Janda, Kenneth, et al. 1998. The Politics of American Governmeni. Brief ed. New York: St. Martin's.
Lasser, William. 1999. American Politics: The Enduring Constitution. 2nd ed. New York: Houghton Mifflin.

O'Connor, Karen, and Larry Sabato. 1998. The Essentials of American Government: Continuity and Change. Boston: Allyn and Bacon.

Ripley, Randall, and Grace Franklin. 1999.

\footnotetext{
"Bureaucratic-Congressional Relations: Separate Institutions, Shared Powcrs." In Readings in American Government and Politics, 3rd ed., ed. Randall Ripley and Elliot Slotnick. Boston: Allyn and Bacon.

Wayne, Stephen, et al. 1998. The Politics of American Government. Brief ed. New York: St. Martin's.
} 